\title{
Alternative Sources of Petrochemical from Biomass Energy: A Review
}

\section{Vivek Kumar Singh* \\ University of Coimbra, Portugal}

Submission: September 19, 2017; Published: September 25, 2017

*Corresponding author: Vivek Kumar Singh, Energy for Sustainability Initiative, MIT-Portugal Program, University of Coimbra, Portugal, Email: Viv.jsingh@gmail.com

\section{Abstract}

In world $\mathrm{CO}_{2}$ emissions are projected to be $80 \%$ higher by 2030 than the current levels. As the energy requirement is increasing day-byday and conventional fuel sources are depleted. The time has come to search for an alternative energy order to meet the needs of demanding energy. The driving force for searching new avenues for energy is 3ES i.e. Economic development, energy security, environmental and social sustenance through Bioenergy based biochemical conversation technology to a new roadmap for the clean and low-carbon economy (Figure 1). The possibility to secure collection mechanism to sufficient biomass resource to support a large-scale petrochemical-style industry given the size of its feedstock demand relative to sustainable energy demand.

Keywords: Biomass; Biochemical; Energy mix; Petrochemical

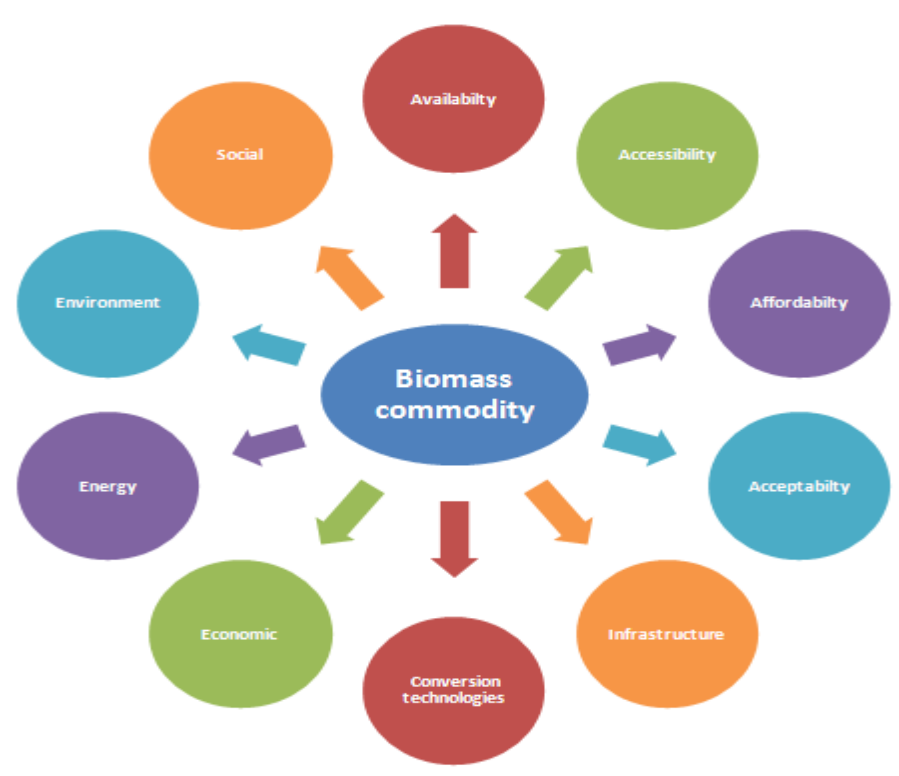

Figure 1: Graphical abstract for biomass commodity.

\section{Introduction}

Bioenergy is energy from organic matter (biomass), i.e. all materials of biological origin that is not embedded in geological formations (fossilised) [1]. Biomass is a renewable source wood, crops, seaweed, animal wastes- that can be utilized as an energy source. Biomass is presumably our most old source of energy after the sun. For a thousand number of years, individuals have consumed wood to heat their homes and cook their food. Biomass gets its energy from the sun. All organic matter contains stored energy from the sun. Photosynthesis process, sunlight gives plants the energy they need to convert 


\section{Recent Advances in Petrochemical Science}

water and carbon dioxide into oxygen and sugars. These sugars, called carbohydrates, supply plants and the animals that eat plants with energy. Foods rich in carbohydrates are a useful source of energy for the human body.

Biomass can be used in its original form as fuel, or be refined to various kinds of solid, gaseous or liquid biofuels. These fuels can be used in all sectors of society, for production of electricity, for transport, for heating and cooling, and for industrial processes [1]. Production of primary bioenergy from agricultural resources is closely related to food demand and supply Figure 2 because both energy and food crops are produced using the same agricultural land resources. The total volume of agricultural residue generated is primarily a function of crop production, which is related to the amount of land cultivated (in hectares), the mix of crops raised and crop yields per hectare. Demand for food and energy is determined by developments in a given country's population and economy (indicated by gross domestic product, GDP) [2]. Globally, Biomass energy is maturing up perpetually as an appropriate substitute for petroleum products because of the expanding interest in clean energy, declining fuel reserves, and its contribution towards lessening reliance dependence on crude oil [3]. Biomass is an important component of the renewable energy mix in energy production and worldwide energy mix is about $10 \%$ in total energy production $[1,4]$. Biomass use worldwide could grow by $3.7 \%$ every year from 2010 to 2030 - twice as fast as it did from 1990 to 2010 and global biomass demand would double from 56 exajoules (EJ) in 2010 to 108 EJ by 2030 [2]. Biomass is abundant in nature and broadly dispersed globally with its distribution being dependent on geographical area [3].

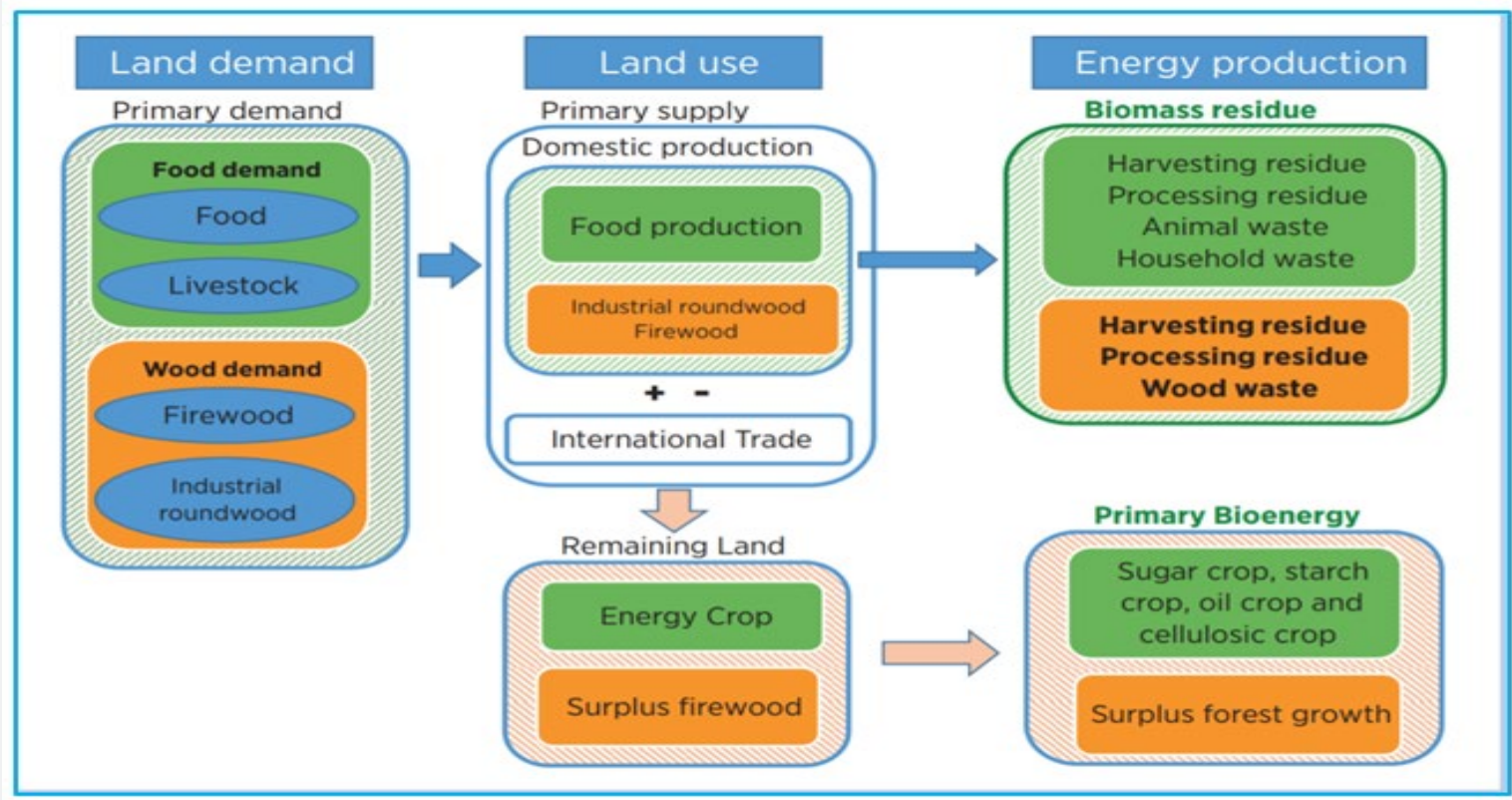

Figure 2: Supply and demand framework of bioenergy.

\section{Biorefinery Concept}

The Biorefinery concept is analogous to an oil refinery. Just as an oil refinery enables the conversion of a range of crude oils into high-specification fuels and chemical feed stocks, a Biorefinery enables the conversion of a range of biomass feed stocks into fuels and chemical feed stocks [5]. IEA Bioenergy Task 42 has developed the following definition for Biorefinery as Bioenergy is the sustainable processing of biomass into a spectrum of marketable products and energy [6]. The development of comparable bio refineries-however not in the sense of a direct copy of petroleum refinery, it is necessary to produce a broad variety of bio based products in an efficient construction set system [7]. Comparison of refineries and bio refineries regarding feed stocks, building block composition, processes, and chemical intermediates produced at commercial scale (Figure 3) Variability of quality of refineries depends on the energy density of fuel and Biorefinery based energy density is quite low Table 1 . The modern chemical engineering designs will maximize the deployment of cost-effective of Biorefinery. The concept of Biorefinery associated various challenges, Similar to multidimensional challenges (A4) as- Accessibility, availability affordability \& Acceptability of resources [8]. 


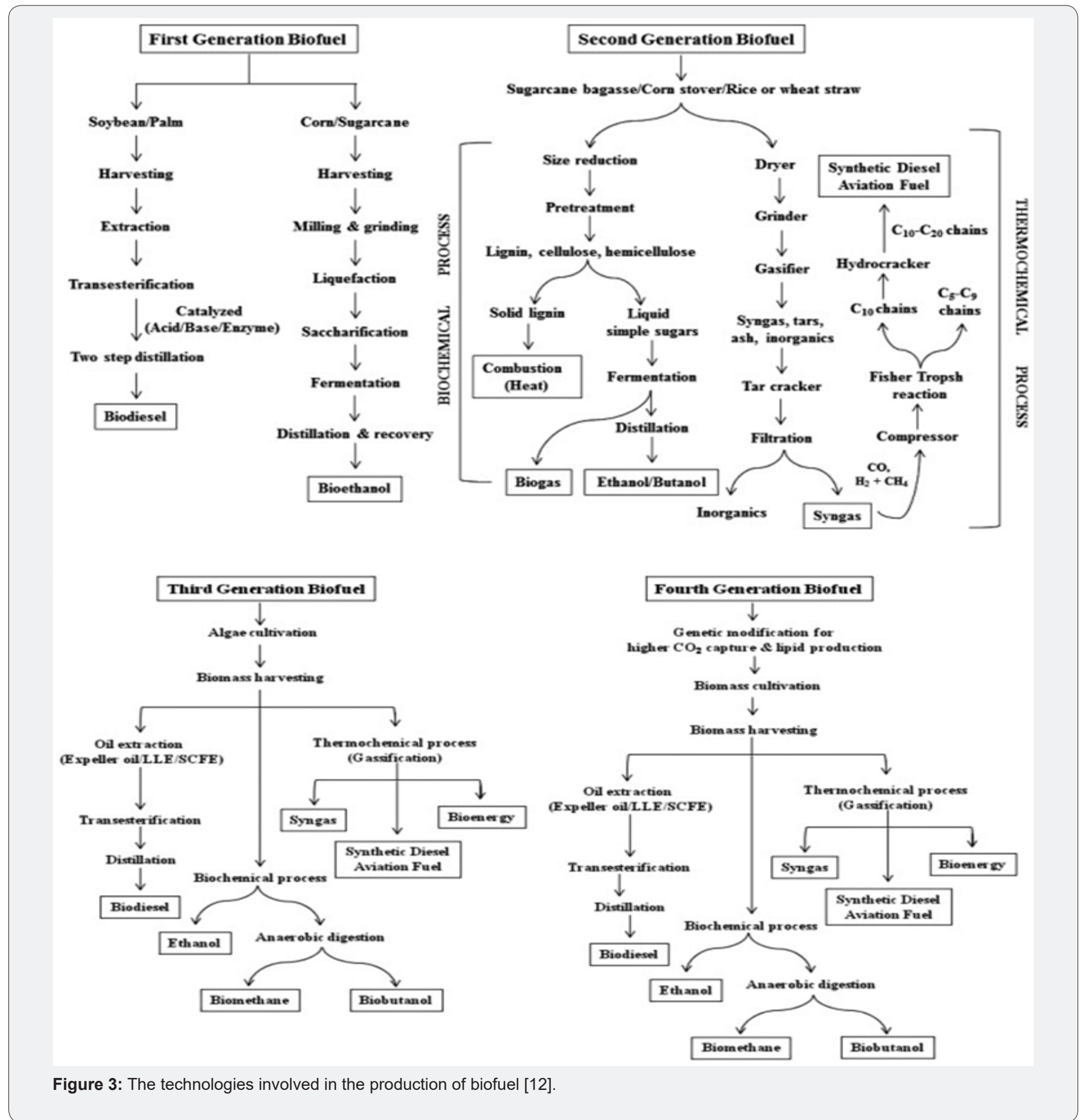

Table 1: Comparison of biomass and fossil fuel energy densities.

\begin{tabular}{|c|c|}
\hline Liquefied Natural Gas & $56 \mathrm{GJ} / \mathrm{t}$ \\
\hline Mineral Oil & $42 \mathrm{GJ} / \mathrm{t}$ \\
\hline Coal & $28 \mathrm{GJ} / \mathrm{t}$ \\
\hline $\begin{array}{c}\text { Biomass (Wood, } 50 \% \\
\text { Moisture) }\end{array}$ & $8 \mathrm{GJ} / \mathrm{t}$ \\
\hline
\end{tabular}

\section{Conversion Technologies}

Biomass resources include wood and wood wastes, agricultural crops and their waste by products, municipal solid waste, animal wastes, waste from food processing and aquatic plants and algae [9]. Biomass is fulfilled to energy demand, including domestic cooking, producing electricity, fuel for vehicles, home heating and various industrial systems. 


\section{Recent Advances in Petrochemical Science}

Biomass can be converted into useful forms of energy using a number of different processes [10]. Biomass contains varying amounts of cellulose, hemicellulose, lignin and small amounts of other organics besides inorganic. The relative proportion of the major organic components in biomass is particularly important in the development of processes for producing other fuels and chemicals [11]. Biomass conversation technologies can be separated into three categories: thermo-chemical, biochemical/biological and Mechanical extraction (with esterification) see- Figure 4 [12]. The thermos-chemical conversion in four processes categorise: combustion, pyrolysis, gasification and liquefaction. Biochemical conversion includes two processes: digestion (production of biogas. methane and carbon dioxide) and fermentation (production of ethanol).

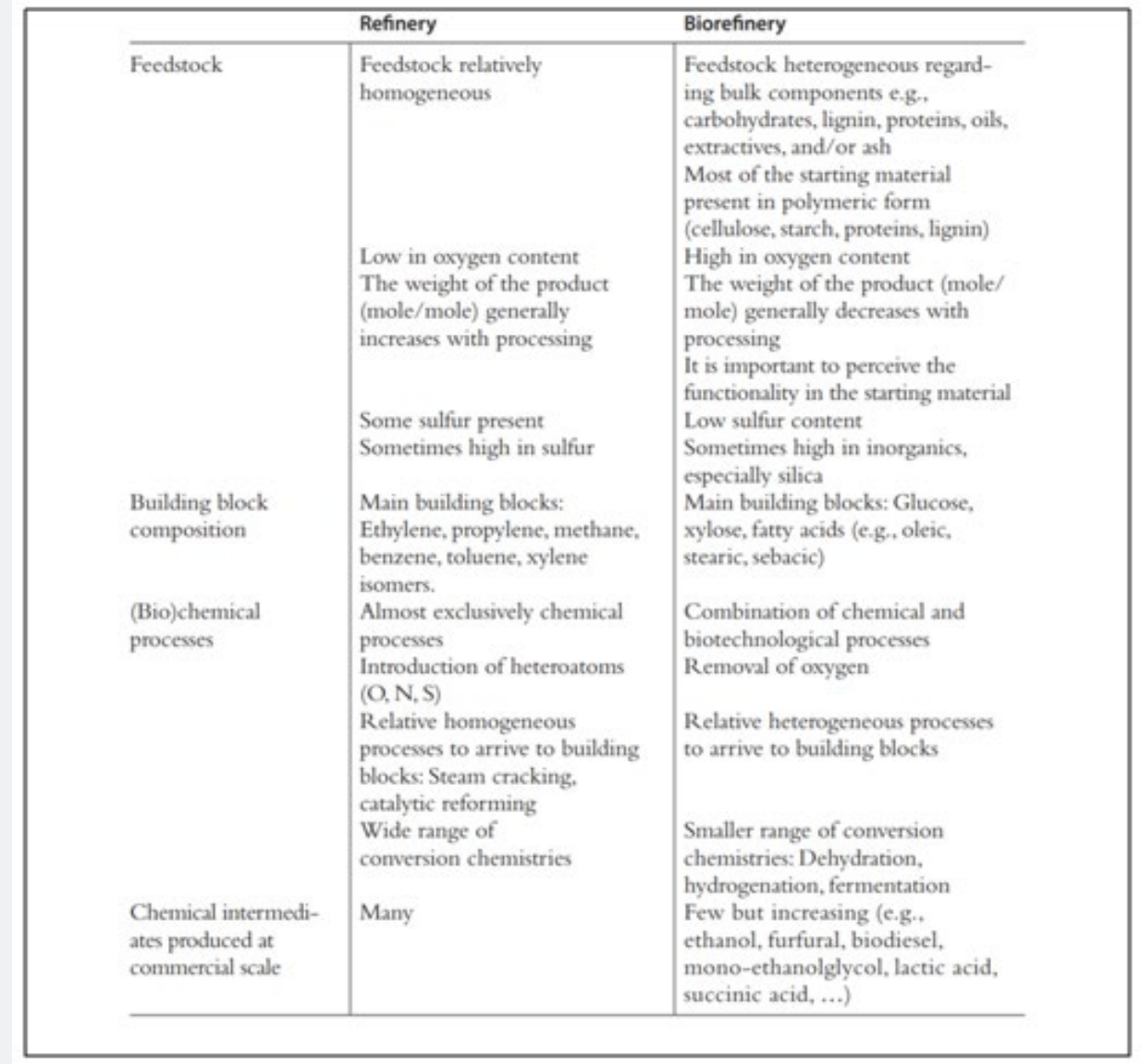

Figure 4: Comparison of refineries and biorefineries [6].

\section{Conclusion}

Biomass utilization as alternative sources of petrochemical still under the research and development, biomass-based energy considers as renewable energy sources. The rapid replacement of fossil-carbon and new energy source creating new job opportunities, and transforming into a green economy. The petrochemical industry is well stabilized, within clusters of feed stocks arriving by ship, rail, pipeline, chemical intermediates and sharing utilities. National and international petrochemical market a huge body of infrastructure access to sufficient resources to support a petrochemical industry. In case of biomass sources is limited in one geographical region to other regions. Transportation of biomass infrastructure needs to develop in the interests of minimizing transportation costs and carbon footprint.

\section{References}

1. World Energy C (2016) World Energy Resources Bioenergy.

2. Renewable Energy Agency I (2014) Global Bioenergy Supply and Demand Projections: A working paper for REmap 2030.

3. Ben IJ, Manovic V, Longhurst P (2016) Biomass resources and biofuels potential for the production of transportation fuels in Nigeria. Renew Sustain Energy Rev 63: 172-192.

4. Popp J, Lakner Z, Harangi Rákos M, Fári M (2014) The effect of bioenergy expansion: Food, energy, and environment. Renew Sustain Energy Rev 32: 559-578.

5. Roddy DJ (2013) Biomass in a petrochemical world. Interface Focus 3(1): 20120038.

6. De JE, Jungmeier G Bioenergy Concepts in Comparison to Petrochemical Reeneries. Ind Biorefineries White Biotechnol.

7. Naik SN, Goud VV, Rout PK, Dalai AK (2010) Production of first and second generation biofuels: A comprehensive review. Renew Sustain Energy Rev 14(2): 578-597. 
8. Fuller S, McCauley D (2016) Framing energy justice: perspectives from activism and advocacy 11: 1-8.

9. Demirbaș A (2001) Biomass resource facilities and biomass conversion processing for fuels and chemicals. Energy Convers Manag 42(11): 1357-1378.

10. McKendry P (2002) Energy production from biomass (part 2): conversion technologies. Bioresour Technol 83(1): 47-54.
11. Abbasi T, Abbasi SA (2010) Biomass energy and the environmental impacts associated with its production and utilization. Renewable and Sustainable Energy Reviews 14(3): 919-937.

12. Dutta K, Daverey A, Lin JG (2014) Evolution retrospective for alternative fuels: First to fourth generation. Renew Energy 69: 114-122.

\section{Your next submission with Juniper Publishers will reach you the below assets}

Commons Attribution 4.0 Licens

DOI: $10.19080 /$ RAPSCI.2017.03.555610
- Quality Editorial service

- Swift Peer Review

- Reprints availability

- E-prints Service

- Manuscript Podcast for convenient understanding

- Global attainment for your research

- Manuscript accessibility in different formats ( Pdf, E-pub, Full Text, Audio)

- Unceasing customer service

Track the below URL for one-step submission https://juniperpublishers.com/online-submission.php 